\title{
Four mutations in the porphobilinogen deaminase gene in patients with acute intermittent porphyria
}

Gunnel Lundin, Jamileh Hashemi, Ylva Floderus, Stig Thunell, Erling Sagen, Astrid Lægreid, Wassif Wassif, Timothy Peters, Maria Anvret Stockholm, Sweden Y Floderus

$S$ Thunell

Department of Clinical Chemistry, University Hospital, N-7006 Trondheim, Norway

E Sagen

UNIGEN, Institute of Biotechnology,

University of

Trondheim, N-7030

Trondheim, Norway

A Lægreid

Department of Clinical Biochemistry, King's College School of Medicine \&

Dentistry,

Bessemer Road

London SE5 9PJ, UK

W Wassif

$\mathrm{T}$ Peters

Correspondence to:

Dr Lundin.

Received 15 May 1995

Revised version

accepted for publication

31 August 1995

( $\mathcal{H}$ Med Genet 1995;32:979-981)

Fifty-nine mutations have been published in the porphobilinogen deaminase (PBGD: hydroxymethylbilane synthase, EC 4.3.1.8) gene associated with the autosomal dominant disease acute intermittent porphyria (AIP).$^{1-10}$ PBGD is the third enzyme involved in haem synthesis, and AIP patients have a partial deficiency of the enzyme activity. When the demand for haem is increased, for example by alcohol or drug usage, the precursors ALA ( $\delta$-aminolaevulinic acid) and PBG (porphobilinogen) accumulate in tissues and are probably responsible for the toxic effects in the neuropsychiatric porphyrias. AIP seldom presents before puberty, many carriers are asymptomatic, and the disease can often be difficult to diagnose. The symptoms are varied with sometimes severe attacks of abdominal pain, paralysis, mental disturbances, and autonomic dysfunction. ${ }^{11}$

The PBGD gene spans over $10 \mathrm{~kb}$ and comprises 15 exons. Mutations have been reported

\begin{abstract}
Department of
Clinical Genetics/

Molecular Medicine,

Karolinska Hospital,

S-171 76 Stockholm,

Sweden

G Lundin

J Hashemi

M Anvret

Porphyrias Service Sweden, St Göran's Hospital, S-112 81

Abstract

We have detected four different mutations in the porphobilinogen deaminase (PBGD) gene in acute intermittent porphyria (AIP) families from England, Norway, and Sweden. A splicing mutation in the first position of intron 8 (Int8 +1) was found in a family from England and a missense mutation in exon $12\left(\mathrm{Glu}^{250}\right)$ was detected in a Norwegian family. Two mutations were identified in Swedish families, one splicing mutation in the first position of intron $3($ Int $3+1)$ and one missense mutation in exon $8\left(\right.$ Pro $\left.^{119}\right)$.
\end{abstract}

Primers used for exon amplification of the PBGD gene before single stranded sequencing

\begin{tabular}{|c|c|c|}
\hline Exon 1 & $\begin{array}{l}\text { NEP-123,F } \\
\text { Int } 1,128, R\end{array}$ & 5'-GTCAGACTGTAGGACGACCT-3' \\
\hline Exon 3 & Int $2, F$ & $\begin{array}{l}\text { 5'-ACGACTGAGGATGGCAACCT-3' } \\
\text { 5'-TCCTTTCTTCCAAGCCAGTGA-3' }\end{array}$ \\
\hline & Int $3, R$ & 5'-ССАССССАТСТССТTСATAC-3' \\
\hline \multirow[t]{2}{*}{ Exon 4} & Int $3, F$ & 5'-AAAGAGTCTGAGCCGTGGCT-3' \\
\hline & Int $4, R$ & 5'-TGTTCTCTCCTCTCGGGGTA-3' \\
\hline Exon 5 & JS39 & 5'-CCATCATGAATCGTAGCACAG-3' \\
\hline \multirow[t]{2}{*}{ Exon 8} & $\begin{array}{l}\text { JS5 } \\
\text { JS109 }\end{array}$ & $\begin{array}{l}\text { 5'-TCATTCTTCTCCAGGGCATG-3' } \\
\text { 5'-CCAGTGAGTTGGCCAATCGAGA-3' }\end{array}$ \\
\hline & Int8, $R$ & 5'-CCTGCATCTTCTGGGCACAT- $3^{\prime}$ \\
\hline \multirow[t]{2}{*}{ Exon 9} & Int8K & 5'-TGCCCAGAAGATGCAGGGAT-3' \\
\hline & $\begin{array}{l}\text { Int9, R } \\
\text { Int9,F }\end{array}$ & $\begin{array}{l}\text { 5'-CAGAGCCCTCTAGACCTTGT-3' } \\
\text { 5'-GGGAAAGACAGACTCAGGCA-3' }\end{array}$ \\
\hline Exon 10 & Phi10 & 5'-TGAACGTATATCGCTTTCACAC-3' \\
\hline \multirow[t]{2}{*}{ Exon 12} & Int $11, F$ & 5'-GTCCCATGCTTTCGGCCATT-3' \\
\hline & Int $12, \mathbf{R}$ & 5'-ATCTTCCCTGCCACCTTTCC-3' \\
\hline \multirow[t]{2}{*}{ Exon 14} & Int 13,F & 5'-CTTCCTGTGCAATCCCAGGT-3' \\
\hline & Int $14, \mathbf{R}$ & 5'-GGAGGTGGGATTTGGTGAGA-3' \\
\hline
\end{tabular}

in all regions of the gene except in exons 2 and 11. The hot spots for mutations are exons 10 and 12. In Swedish families, six mutations have been found previously, one in exon $8\left(\mathrm{Arg}^{116}\right)$, four in exon $10\left(\mathrm{Arg}^{167}, \operatorname{Arg}^{173}, \operatorname{Trp}^{198}\right.$, and $\left.\mathrm{Arg}^{201}\right)$, and one, a splicing mutation, at the border of intron 9 and exon $10 .^{1213}$ The mutation affecting $\operatorname{Trp}^{198}$ in exon 10 originates from Arjeplog in northern Sweden and is the most common mutation among Swedish AIP patients. $^{12}$

\section{Materials and methods}

PATIENTS

Genomic DNA from one Norwegian, one English, and two Swedish AIP families were investigated.

The Norwegian family belongs to a large kindred originating from the district of Trøndelag in central Norway. A total of 28 family members were included in the study, 22 unaffected subjects and six gene carriers. The biochemical findings and linkage analysis have previously been described. ${ }^{14}$ Seven subjects selected from a large, well characterised English family were investigated. Three of them were diagnosed as AIP patients and three as unaffected. One family member was a possible gene carrier and treated as being at risk of AIP, though she had equivocal PBGD enzyme activity and had no AIP symptoms. ${ }^{15}$ The two Swedish families comprised 11 AIP carriers, 10 unaffected subjects, and two additional cases, for whom the results of the conventional diagnostic procedure were inconclusive.

The diagnosis of AIP was established or excluded by family history, clinical symptoms, and biochemical analyses, including porphobilinogen deaminase activity in erythrocytes and urinary excretion of porphobilinogen and $\delta$-aminolaevulinic acid.

\section{DNA SEQUENCING}

Genomic DNA was investigated by single stranded sequencing of exons $1,3,4,5,8,9$, 10,12 , and 14 in the PBGD gene. Primers for exon amplification were designed $52-86$ bases from the exon/intron border (table).

The first PCR amplification was performed in $10 \mathrm{mmol} / 1$ Tris- $\mathrm{HCl}$ buffer, $\mathrm{pH} 8.8$, containing $50 \mathrm{mmol} / 1 \mathrm{KCl}, 1.5 \mathrm{mmol} / 1 \mathrm{MgCl}_{2}$, $0 \cdot 1 \%$ Triton X-100, $150 \mu \mathrm{mol} / 1$ of each dNTP, $25 \mathrm{pmol}$ of each primer, 0.4 units of Dynazyme (Finnzymes Oy), and $100 \mathrm{ng}$ template DNA in 
A
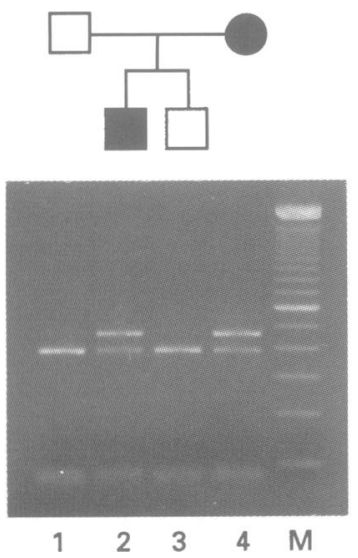

B
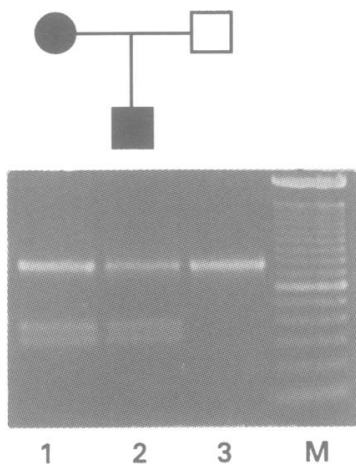

Figure 1 Cleavage with restriction enzymes to identify two of the mutations in the $P B G D$ gene. The marker (M) is a $100 \mathrm{bp} D N A$ ladder. (A) $A 608 \mathrm{bp}$ fragment is $P C R$ amplified and the normal allele is cleaved by BstNI into 381, 82, 75, and 70 bp lanes 1 and 3). The fragments of 82,75 , and $70 \mathrm{bp}$ could be seen as one band in the gel. The splicing mutation in the first position of intron 3 (Int $3+1)$ is abolishing one of the cleavage sites and an additional fragment of $451 \mathrm{bp}$ is visible (lanes 2 and 4). (B) The mutation in exon $8\left(P^{1119}\right)$ creates a cleavage site for XmnI and a PCR amplified fragment of $765 \mathrm{bp}$ is cleaved into two fragments of 412 and $353 \mathrm{bp}$ (lanes 1 and 2). The alleles from the healthy subject are uncleaved (lane 3).

a final reaction volume of $50 \mu \mathrm{l}$. The samples were amplified by 35 cycles of one minute at $94^{\circ} \mathrm{C}, 30$ seconds at $58^{\circ} \mathrm{C}$, and one minute at $72^{\circ} \mathrm{C}$, with an initial denaturing step of seven minutes at $94^{\circ} \mathrm{C}$ and a final extension step of 10 minutes at $72^{\circ} \mathrm{C}$.

From the first PCR, $1 \mu \mathrm{l}$ was used as template in a second, asymmetrical PCR amplification. The conditions of the second PCR were identical, except that the amount of primers were 0.5 pmol (limiting primer) and 50 pmol, with concentration of dNTPs of $25 \mu \mathrm{mol} / 1$.

Single stranded DNA was separated from double stranded DNA on a $4 \%$ polyacrylamide gel under non-denaturing conditions, and the sequencing was performed with Sequenase DNA sequencing kit (Amersham).

\section{RESTRICTION ENZYME CLEAVAGE ASSAY}

Restriction enzyme cleavage was used to screen for the mutations in intron $3(\operatorname{Int} 3+1)$ and
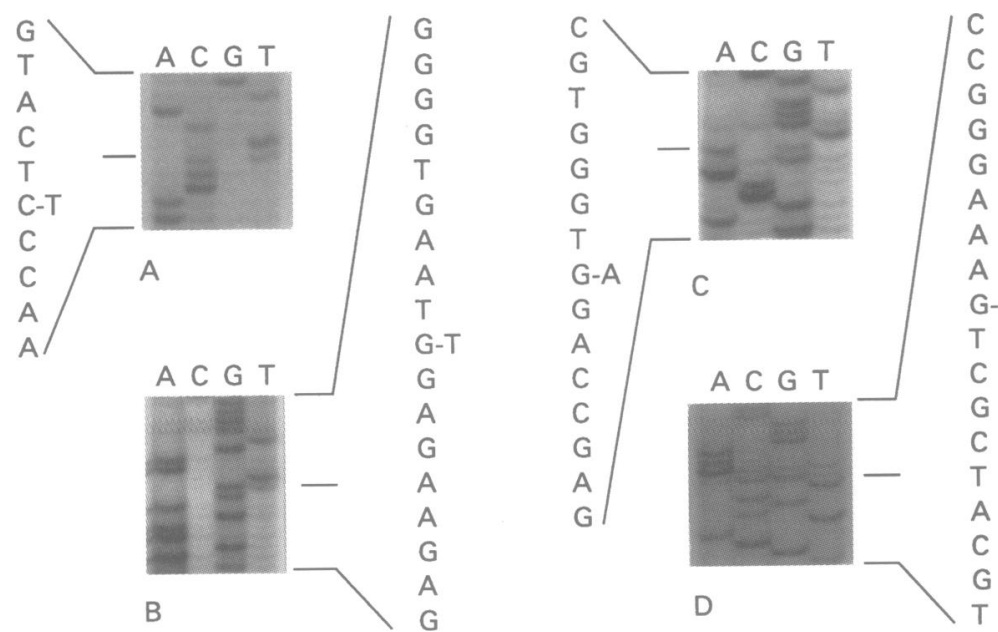

Figure 2 Four new mutations were found in the porphobilinogen deaminase gene. $(A) C$ to $T$ mutation in exon 8 changing Pro ${ }^{119}$ to Leu. (B) A splicing mutation in the first position of intron 8. (C) $A$ splicing mutation in the first position of intron 3 . (D) $G$ to $C$ mutation in exon 12 changing Glu ${ }^{250}$ to Ala. exon $8\left(\right.$ Pro $\left.^{119}\right)$. The splicing mutation Int $3+1$ abolishes a cleavage site for the restriction enzyme $B s t$ NI. A 608 bp fragment was amplified and the normal allele was cleaved by $B s t$ NI into four fragments of $381,82,75$, and $70 \mathrm{bp}$. The mutated allele, on the other hand, created only three fragments of 451,82 , and $75 \mathrm{bp}$. The fragments were visualised on a $2 \%$ NuSieve agarose gel (fig 1A).

The mutation in exon 8 (Pro ${ }^{119}$ ) created a cleavage site for the restriction enzyme $X m n \mathrm{I}$. After PCR amplification of a $765 \mathrm{bp}$ fragment, the mutated allele was cleaved into two fragments of 412 and $353 \mathrm{bp}$. These fragments were separated on a $1 \%$ agarose gel (fig $1 \mathrm{~B}$ ).

\section{Results}

Four new mutations have been found in the PBGD gene in one Norwegian, one English, and two Swedish families with AIP, hitherto uninvestigated (fig 2).

PRO $^{119}$

In a large Swedish family, a C-T substitution in exon 8 (position 356 ) changing Pro $^{119}$ to Leu was found (fig $2 \mathrm{~A}$ ). This mutation alters a cleavage site for the restriction enzyme $X m n I$ and can thus easily be detected (fig 1B). It was found in six AIP patients and one possible carrier, diagnosed by conventional clinical and biochemical methods. Six members of the family, in whom the diagnosis of AIP had been rejected, did not carry the mutation. In addition, DNA from 21 normal Swedish controls were screened for this mutation and were shown to be negative.

\section{SPLICING MUTATIONS}

Two splicing mutations were detected, one at the exon 3 /intron 3 border and the other at the exon 8 /intron 8 border. The mutation found in the first position of intron 8 (Int8 +1$)$, a G to $T$ substitution, was found in a large English family (fig 2B). One of the members of this family had an uncertain AIP diagnosis, and carrier status could now be established.

The other splicing mutation, a $G$ to A substitution in the first position of intron 3 $($ Int $3+1)$, was found in a Swedish family with five AIP patients, one inconclusive, and four unaffected family members (fig 2C). This mutation can be detected by cleavage with the restriction enzyme $B s t$ NI (fig $1 \mathrm{~A}$ ).

$\mathrm{GLU}^{250}$

In a large Norwegian family with six AIP patients and 22 unaffected family members, a mutation was found in exon 12. This $\mathrm{G}$ to $\mathrm{C}$ substitution in position 748 converts $\mathrm{Glu}^{250}$ to Ala (fig 2D). A mutation in this position has previously been reported in two unrelated families. ${ }^{6}$ In these families, however, the substitution was $G$ to $A$, changing glutamine to lysine. The mutation was confirmed by allele 
specific oligonucleotide hybridisation (DOT blot) with the sequence of the mutated allele as probe (data not shown).

\section{Discussion}

Many mutations associated with AIP have been detected in the PBGD gene, including deletions, insertions, missense, nonsense, and splicing mutations. The mutations are scattered throughout the gene, but nearly half of them are found in exons 10 and 12 . Only exons 2 and 13 have no reported mutations. In this paper, we present four new mutations in the PBGD gene. Two of these are splicing mutations in the first position of an intron (Int $3+1$ and Int $8+1$ ), and the other two are missense mutations affecting a single amino acid (Pro ${ }^{119}$ and $\mathrm{Glu}^{250}$ ). In exon 8 , only two mutations were previously reported, altering the same amino acid ( $\operatorname{Arg}^{116}$ ) to tryptophan or glutamine $\mathrm{e}^{791013}$; the mutation we have found affecting Pro ${ }^{119}$ is close to this site. The amino acids coded for by exon 8 are situated close to the active site of the enzyme, connecting domains 1 and $2 .{ }^{16}$ Changes in this part are likely to impair enzyme activity.

Fifteen base changes have been detected in exon 12 associated with AIP, 10 of them located between codons $\mathrm{Leu}^{245}$ and $\mathrm{Leu}^{257}$ in the last third of the exon. ${ }^{24691017-19}$ Consequently the mutation that changes $\mathrm{Glu}^{250}$ to Ala is within one of the hot spot regions for PBGD mutations.

The splicing mutations Int $3+1$ and Int $8+1$ both affect the splice donor site, which probably results in defective splicing.

It is of great benefit to AIP families when the actual mutation in the family is detected. This will not only identify family members with latent porphyria, but unaffected members can also be distinguished with confidence. ${ }^{20} \mathrm{De}$ finitive assignment of AIP status makes it unnecessary for previously equivocal carriers to follow restrictions to prevent AIP attacks and avoids the need for family screening of future generations. In this study we have established carrier status in three subjects where the biochemical analyses were equivocal. In addition to mutations in the PBGD gene itself, there is a possibility of alterations in the regulation of enzyme activity being responsible for the disease and, in that case, the gene promoter regions should also be investigated.
This work was supported by grants from the Swedish Medical Research Council No 9108 (MA), and Torsten and Ragnar Söderberg Foundation (MA).

1 Lundin G, Wedell A, Thunell S, et al. Two new mutations in the porphobilinogen deaminase gene and a screening method using PCR amplification of specific alleles. Hum Genet 1994;93:59-62.

2 Mgone CS, Lanyon WG, Moore MR, et al. Detection of a high mutation frequency in exon 12 of the porphobilinogen deaminase gene in patients with acute intermittent porphyria. Hum Genet 1993;92:619-22.

$3 \mathrm{Gu} \mathrm{X-F,} \mathrm{de} \mathrm{Rooij} \mathrm{F,} \mathrm{de} \mathrm{Baar} \mathrm{E,} \mathrm{et} \mathrm{al.} \mathrm{Two} \mathrm{novel} \mathrm{mutations} \mathrm{of}$ the porphobilinogen deaminase gene in acute intermittent porphyria. Hum Mol Genet 1993;2:1735-6.

4 Daimon $M$, Yamatani $K$, Igarashi $M$, et al. Acute intermittent porphyria caused by a $\mathrm{G}$ to $\mathrm{C}$ mutation in exon 12 of the porphobilinogen deaminase gene that results in 12 of the porphobilinogen deaminase gene that
exon skipping. Hum Genet 1993;92:549-53.

5 Llewellyn DH, Whatley S, Elder GH. Acute intermittent porphyria caused by an arginine to histidine substitution porphyria caused by an arginine to histidine substitution
(R26H) in the cofactor-binding cleft of porphobilinogen (R26H) in the cofactor-binding cleft of porphot
deaminase. Hum Mol Genet 1993;2:1315-16.

6 Gu X-F, de Rooij F, Voortman G, et al. Detection of eleven mutations causing acute intermittent porphyria using denaturing gradient gel electrophoresis. Hum Genet 1994; 93:47-52.

7 Mgone CS, Lanyon WG, Moore MR, et al. Identification of five novel mutations in the porphobilinogen deaminase gene. Hum Mol Genet 1994;3:809-11.

8 Daimon $M$, Yamatani $K$, Igarashi $M$, et al. Acute intermittent porphyria caused by a single base insertion of $\mathrm{C}$ in exon 15 of the porphobilinogen deaminase gene that results in a frame shift and premature stopping of translation. Hum Genet 1994;93:533-7.

9 Chen $\mathrm{CH}$, Astrin $\mathrm{KH}$, Lee G, et al. Acute intermittent porphyria: identification and expression of exonic mutporphyria: identification and expression of exonic mutations in the hydroxyme
Invest 1994;94:1927-37.

10 Kauppinen R, Mustajoki S, Pihlaja $\mathrm{H}$, et al. Acute intermittent porphyria in Finland: 19 mutations in the porphobilinogen deaminase gene. Hum Mol Genet 1995;4: $215-22$.

11 Kappas A, Sassa S, Galbraith RA, et al. The porphyrias. In: Scriver CL, ed. The metabolic basis of inherited disease. New York: McGraw-Hill, 1989:1305-65.

12 Lee JS, Anvret $M$. Identification of the most common mutation within the porphobilinogen deaminase gene in Swedish patients with acute intermittent porphyria. Proc Natl Acad Sci USA 1991;88:10912-15.

13 Lee JS. Molecular genetic investigation of the human porphobilinogen deaminase gene in acute intermittent porphyria. Stockholm: Reproprint AB, 1991:1-50.

14 Sagen E, Lægreid A, Anvret M, et al. Genetic carrier detection in Norwegian families with acute intermittent portection in Norwegian families with acute inter
phyria. Scand $\mathcal{F}$ Lab Invest 1993;53:687-91.

15 Wassif WS, Deacon AC, Floderus Y, et al. Acute intermittent porphyria: diagnostic conundrums. Eur $\mathcal{f}$ Clin Chem Clin porphyria: diagnostic con

16 Brownlie PD, Lambert R, Louie GV, et al. The threedimensional structures of mutants of porphobilinogen deaminase: toward an understanding of the structural basis of acute intermittent porphyria. Protein Sci 1994;3: 1644-50.

17 Grandchamp B, Picat C, de Rooij F, et al. A point mutation G-A in exon 12 of the porphobilinogen deaminase gene results in exon skipping and is responsible for acute intermittent porphyria. Nucleic Acids Res 1989;17:6637-49.

18 Delfau MH, Picat C, de Rooij F, et al. Molecular heterogeneity of acute intermittent porphyria: identification of four additional mutations resulting in the CRIM-negative subtype of the disease. Am 7 Hum Genet 1991;49:421-8.

19 Mgone CS, Lanyon WG, Moore MR, et al. Detection of seven point mutations in the porphobilinogen deaminase gene in patients gene in patients with acute intermittent porphyria, by 1992;90:12-16.

20 Andersson C, Thunell S, Floderus Y, et al. Diagnosis of acute intermittent porphyria in northern Sweden: an evaluation of mutation analysis and biochemical methods. $\mathcal{f}$ ation of mutation analysis and
Intern Med 1995;237:301-8. 